\title{
REFORMULASI INDEKS PENGUNGKAPAN ENTITAS SYARIAH DAN KEUNIKAN BERAGAM KEBIJAKAN NILAI SYARIAH DI BEBERAPA NEGARA
}

\author{
Krisno Septyan \\ Universitas Pembangunan Nasional "Veteran" Jakarta \\ kris.tyan26@gmail.com
}

\begin{abstract}
This research's aim is to giving the altervative disclosure index for shariah company. Researcher's used shariah enterprise theory to make a new disclosure index, the first step is combine among disclsoure index are AAOIFI Index, Islamicity disclsore index and Islamic Social Reporting, then eliminate a few point form those index based on shariah etics, academic's perspective and regulation in some countries. In other side, researcher's used content analysis method in six countries are Indonesia, Malaysia, Bahrain, Qatar, Iran and UK. Result is a make new disclosure index that showing the God is a highest stakeholder in company, care about all stakeholder such as employee, nature, duafa etc. While, content analysis' result shows new found things related unique policy in each company in some countries.
\end{abstract}

Keywords: Disclosure Index, Shariah Enterprise Theory, Content Analysis.Unique Policy

\section{PENDAHULUAN}

Pelaporan keuangan merupakan tools bagi manajemen dalam pengambilan keputusan, yang di dalamnya harus termuat pengungkapan-pengungkapan pada entitas tertentu. Namun belum ada ketentuan yang mengatur pengungkapan untuk entitas syariah yang sekarang sedang berkembang di Indonesia.

Sejarah perkembangan bank syariah dimulai dari Mesir dengan berdirinya Mit Ghamr Bank. Karena keberhasilan mengelola bank syariah, diberbagai dunia mulai membuka bank syariah dan konfrensi Islam dalam gagasan membentuk bank syariah. Di Indonesia berawal dari Bank Muamalat sebagai bank syariah pertama di Indonesia mulai diikuti oleh bank syariah lain, ini disebabkan karena dukungan dari peraturan Bank Indonesia No. 21 Tahun 1998 tentang dual banking system. Sehingga keberadaan bank syariah mulai memenuhi kebutuhan masyarakat untuk produk-produk perbankan syariah dengan cara yang Islami, salah satunya dengan menghindari sifat riba, gharar (ketidakpastian) seperti suku bunga yang fluktuatif tidak menentu. Bank syariah hadir dalam operasional yang transparan dalam transaksi kepada para nasabahnya untuk menghindari sifat-sifat yang tidak syariah.

Keluarnya fatwa MUI no. 1 tahun 2004 yang menyebutkan bahwa bunga dan persentasenya haram, membuat kedudukan berbagai lembaga keuangan syariah semakin merebak di Indonesia. Sebagai contoh real pada tahun 1998 telah membuktikan salah satu jenis lembaga keuangan syariah yaitu bank syariah mampu bertahan dalam terjangan krisis. Bukti lain yang memperkuat perkembangan entitas syariah adalah Pembentukan Standar Akuntansi Keuangan Syariah karena beragam transaksi syariah yang ada, sehingga munculnya PSAK No. 101 sampai No. 110 memberi kesan pengembangan atas PSAK sebelumnya dengan transaksi syariah yang lebih terperinci, PSAK tersebut bukan hanya ditujukan pada Bank syariah seperti PSAK No. 59, melainkan juga pada seluruh entitas syariah yang melakukan transaksi syariah dan hanya menyebutkan pengungkapan lebih ditekankan pada 
transaksi-transaksi syariahnya. Norhadi (2006) menyatakan bahwa PSAK Syariah memang perlu namun entitas syariah di Indonesia masih sedikit sekali yang go public.

Penentuan PSAK Syariah tersebut banyak berkiblat dari organisasi Islam di Timur Tengah bernama Accounting and Auditing Organization of Islamic Financial Instituion (selanjutnya disebut AAOIFI), (Harahap, 2001). Organisasi ini mengeluarkan banyak standar seperti standar pengungkapan untuk bank syariah, standar pengungkapan untuk asuransi syariah, standar tata kelola perusahaan dan standar lainnya untuk lembaga keuangan syariah. Hasan dan Lewis (2007) dalam Handbook of Islamic Banking menyatakan bahwa Islamic Financial Institution (IFI) juga memerlukan standar atas pelaporan keuangan dan guideline seperti IFRS yang diterbitkan IASB. Maka Standar Syariah diterbitkan juga oleh AAOIFI. Harahap (2001), dan Vinnicombe (2010) dan Triyuwono (2012) menyatakan survey yang sama bahwa AAOIFI menjadi pusat atas standar pelaporan keuangan untuk entitas syariah.

Harahap (2002) dalam penelitiannya menemukan bahwa standar pengungkapan yang diterbitkan AAOIFI masih memiliki paham filosofi kapitalis yang kental. Sehingga standar pengungkapan lebih ditujukan pada pelaporan keuangan entitas syariah. Beberapa peneliti pun banyak mengembangkan indeks pengungkapan dan teori terkait agar entitas syariah dapat menunjukan hakikatnya sebagai entitas yang memenuhi prinsip dan hukum Islam.

Seperti yang dilakukan Triyuwono (2012) mengkonstruksikan Shariah Enterprise Theory yang menggambarkan secara seimbang memenuhi nilai-nilai akutansi dan nilai-nilai syariah. Sedangkan hasil empiris dilakukan oleh Hameed et al (2003) mencoba memformulasikan indeks pengungkapan yang lebih komprehensif untuk entitas syariah namun lebih ditekankan pada Corporate Governance karena banyak menyerap pada peraturan yang ada di Malaysia dan AAOIFI. Formulasi indeks tersebut disebut dengan Islamicity Disclosure Index (IDI) terdiri dari 3 kategori penting pengungkapan untuk bank Islam yaitu shariah compliance, governance dan social/environmental.

Formulasi indeks pengungkapan lainnya untuk entitas syariah adalah Islamic Social Reporting (ISR) yang merupakan modifikasi beberapa peneliti terdahulu Haniffa (2002), Maali et al (2006) dan Othman et al (2009). Pada indeks ini, walaupun terlihat secara komprehensif seperti memiliki pelaporan keuangan, namun lebih ditujukan pada pertanggungjawaban social apakah halal atau haramnya suatu produk untuk konsumen.

Selain yang membedakan bank syariah dengan bank konvensional dalam segi produk adalah struktur organisasi pada bank syariah cukup unik dan berbeda dari entitas non-syariah, yaitu memiliki Dewan Pengawas Syariah (DPS). Di Indonesia, DPS diatur pada UUPT No. 40 Tahun 2007 menyebutkan "Perseroan yang menjalankan kegiatan usaha berdasarkan prinsip syariah selain mempunyai Dewan Komisaris juga wajib mempunyai DPS" hal ini disebutkan juga dalam buku standar governance yang diterbitkan AAOIFI. Dewan Pengawas Syariah harus mengeluarkan pernyataan yang berisikan apakah lembaga keuangan syariah sudah syariah. Tentunya dengan pernyataan tersebut harus didukung bukti yang kuat, salah satunya dengan pengungkapan-pengungkapan yang lebih bisa menunjukan hakikat atas lembaga keuangan syariah tersebut. Dewan Pengawas Syariah di bank syariah diharapkan memberikan nilai tambah dalam laporan tahunan perusahaan. Eksistensi DPS tidak hanya sebagai pemenuhan sebuah persyaratan perundang-undangan, tapi juga dapat memberikan kontribusi aktif tidak hanya dalam operasional perbankan syariah dan memberikan masukan atas perkembangan entitas syariah yang didudukinya.

Prasetyoningrum (2004) bahwa terjadi penurunan kepatuhan bank syariah terhadap prinsip syariah. Berdasarkan hasil penelitian tersebut ditemukan adanya keraguan masyarakat terhadap kepatuhan syariah di bank syariah. Salah satunya dikarenakan Dewan Pengawas Syariah (DPS) belum mengawasi secara optimal. Namun kesadaran atas pengungkapan pada entitas syariah hanya sebatas pada kepatuhan regulasi yang mengatur syariah tersebut, bukan kesadaran murni karena syariah merupakan pertanggungjawaban kepada masyarakat, alam dan Tuhan, selain itu masih sedikitnya entitas syariah di Indoensia yang go public 
sehingga standar yang digunakan pun banyak mengadopsi dari standar pengungkapan dari Negara Islam.

Berdasarkan argumentasi Harahap (1997) mengandung makna bahwa akuntansi syariah lebih memiliki corak sosial dan berorientasi pada kepentingan stakeholder dan stockholder. Dijelaskan lebih mendalam oleh Tiyuwono (2000) bahwa pertanggungjawaban 
akuntansi syariah bukan hanya dari manajemen pemilik perusahaan saja kepada pemegang saham, tetapi juga sebagai pertanggungjawaban kepada stakeholder dan Tuhan. Lebih ditegaskan lagi oleh Mulawarnan (2007) bahwa Tuhan merupakan stockholder tertinggi dalam perusahaan.

Syariah hanya sebuah sistem yang sesuai dengan ajaran agama, setiap agama memiliki syariah masing-masing. Hanya saja entitas-entitas syariah di Indonesia seperti bank syariah sudah merujuk pada sistem yang islami. Dan sistem tersebut dikhususkan untuk umat islam, tapi semua umat dapat memanfaatkan jasa-jasa entitas syariah tersebut. Karena setiap entitas syariah yang berhubungan dengan nasabah menyadari bahwa entitas merupakan pengelola dari amanah yang telah diberikan oleh nasabah itu tadi.

Selain itu, menurut Harahap (2001) standar akuntansi syariah banyak mengadopsi dari AAOIFI, ini merupakan hikmah karena Islam bersifat universal, sehingga harmonisasi akuntansi syariah bisa diberlakukan di berbagai Negara.

\section{METODE PENELITIAN}

\subsection{Reformulasi Indeks Pengungkapan}

Peneliti mencoba menggabungkan indeks-indeks yang sudah ada dengan dasar syariah enterprise theory. Kemudian mengeliminasi berdasarkan etika syariah, sudut akedemis serta regulasi di beberapa negara. Adapaun kajian literatur untuk membentuk indeks tersebut adalah sebagai berikut

Awalnya akuntansi berpedoman pada proprietary theory yaitu memiliki arti bahwa entitas bertanggung jawab atas kekayaan pemegang saham atau dengan kata lain pemegang saham merupakan pusat pertanggungjawaban (pemegang saham sebagai participant). Kemudian toeri tersebut berkembang menjadi entity theory dimana perkembangan dan keberlanjutan perusahaan menjadi hal penting dan terpisah dengan pemilik saham itu sendiri (pemegang saham menjadi outsider), maka timbul hubungan principal and agent. Triyuwono (2012) menyatakan bahwa kedua teori tersebut sangat memiliki nilai egoistic yaitu hanya mementingkan pihak manajemen dan pemilik saham dengan mengabaikan stakeholder lainnya. Padahal dalam syariah melarang kekayaan hanya beredar pada golongan tertentu. Dengan konsep khalifahtulloh fil Ardh dalam teori akuntansi syariah menerangkan bahwa manusia sebagai pemegang amanah untuk menyebarkan kesejahteraan kepada seluruh stakeholder, maka Shariah enterprise theory dianggap menjadi solusi.

Triyuwono (2012) menyatakan bahwa Shariah Enterprise Theroy merupakan dasar kegiatan bank syariah secara menyeluruh karena teori ini memperhatikan seluruh stakeholder dibanding teori-teori sebelumnya. Stakeholder yang dimaksud tidak hanya kepada pihakpihak yang berkontribusi langsung terhadap profit, tapi juga kepada pihak yang tidak berkontribusi secara langsung dalam menghasilkan profit, termasuk mengakui keberadaan Tuhan sebagai stakeholder tertinggi.

Harahap (1997) dalam Triyuwono (2012) yang menyatakan “... Enterprise Theory menjelaskan bahwa akuntansi harus melayani bukan saja pemilik perusahaan, tetapi juga masyarakat" ditambahkan oleh Triyuwono (2012) menyatakan "akuntansi syariah tidak saja sebagai bentuk akuntabilitas manajemen terhadap pemilik perusahaan, tetapi juga sebagai akuntabilitas kepada stakeholder (termasuk alam) dan Tuhan"

Namun akuntansi masih memiliki sifat mendunia yang memahami bahwa perusahaan merupakan amanah, maka manajemen sebagai pengelola harus memberikan laporan yang dapat diukur secara manusiawi yaitu melalui pengungkapan yang memberikan informasi bahwa entitas syariah tersebut memperhatikan seluruh stakeholder. Sehingga penyajian pengungkapan tersebut memberikan informasi bahwa entitas memperhatikan hubungan dengan manusia (stockholder, investor, karyawan, nasabah dan sosial) dan hubungan entitas dengan alam.. Pengungkapan kepada Tuhan tidak harus tertulis dalam laporan tahunan perusahaan karena meyakini Tuhan Maha Mengetahui ( $a^{\prime}$ lim). 
Dengan demikian, entitas syariah secara seimbang dapat menggambarkan nuansa akuntansi dan syariah seperti yang dinyatakan oleh Triyuwono (2006 dan 2012) memperkenalkan Epistemologi Berpasangan, yang terdapat dalam (QS. 36:36). Contoh sederhana epistemologi berpasangan adalah adanya siang dan malam, laki-laki dan perempuan, akuntansi syariah pun yang menyirat makna-makna duniawi dan ukhrowi. Epistemologi berpasangan memberikan kesan seperti Yin dan Yang yang saling menyeimbangkan. Adapun isi dari QS 36.36 adalah sebagai berikut:

"Maha Suci Tuhan yang telah menciptakan pasangan-pasangan, baik dari apa yang ditumbuhkan oleh bumi dan dari diri mereka maupun dari apa yang tidak mereka ketahui."

Sebagai bentuk suatu hubungan akuntansi syariah yang peduli terhadap sesama, membangun suatu bentuk laporan keuangan tambahan yang tidak dimiliki entitas lainnya selain entitas syariah yaitu dalam bentuk Laporan Sumber dan Penggunaan Zakat, dan Laporan Sumber dan Penggunaan Dana Kebajikan (PSAK No. 101 dan Standar AAOIFI No. 1). Kontribusi aktif entitas syariah memberikan suatu pemahaman bahwa pentingnya berbagi kepada sesama manusia yang membutuhkan.

Metafora Zakat diperkenalkan Triyuwono (2000) yang menyatakan bahwa seharusnya perubahan pemikiran suatu entitas untuk mencapai profit yang maksimum (profit oriented) diubah menjadi stockholder dan zakat oriented untuk pembayaran zakat yang maksimum, sehingga "laba" merupakan intermediary antara operasional perusahaan kepada pemiliki dan kepada yang berhak membutuhkan (mustahiq). Sama halnya seperti sedekah yang sifat kerelaan manusia untuk memberikan sebagian hartanya untuk ditransfer dan dipercayakan kepada bank syariah. Baik disadari atau tidak, bank syariah sudah melakukan investasi yang sangat menguntungkan seperti yang telah ditetapkan dalam ayat di bawah ini:

"Perumpamaan (nafkah yang dikeluarkan oleh) orang-orang yang menafkahkan hartanya di jalan Allah adalah serupa dengan sebutir benih yang menumbuhkan tujuh butir, pada tiap-tiap butir seratur biji. Allah melipatgandakan (ganjaran) bagi siapa yang Dia kehendaki. Dan Allah maha luas (Karunia-Nya) lagi maha mengetahui" (QS Al-baqarah: 261)

Zakat dan sedekah merupakan hubungan hablum minannas pada external entitas bisnis. Sedangkan pada pihak internal kita dapat menerapkan kesejahteraan karyawan yang kita pekerjakan. "Berikanlah gaji dan upah kepada karyawan sebelum kering keringatnya dan beritahukan ketentuan gaji/upahnya, terhadap apa yang dikerjakan" (hadits).

Hadits tersebut berkaitan dengan kesejahteraan karyawan dan pembayaran upah yang tepat waktu. Pelatihan dan bentuk keterampilan karyawan juga merupakan suatu dukungan dalam membesarkan suatu entitas bisnis dengan orang-orang yang berkompeten dan penuh amanah untuk mencapai kesejahteraan karyawan. Bentuk lain dari hablum minannas adalah kepuasan pelanggan yang menggambarkan suatu kejujuran berbisnis dan beretika dalam menjalankan operasi usaha.

Komponen lain dalam pengungkapan adalah lingkungan alam, entitas syariah yang menjalankan sudah menggunakan sumber daya alam dalam seperti transportasi, pemakaian kertas. Alam tidak membutuhkan uang untuk dibayar seperti stakeholder lainnya, namun kesadaran entitas dalam melestarikan alam menjadi kontribusi yang sangat diperlukan. Sehingga komponen ini termasuk penting dalam indeks pengungkapan.

Untuk pengukuran pengungkapan, peneliti mengkombinasi standar dari Timur Tengah dan Malaysia, adapun standar dari Timur Tengah yang diterbitkan oleh AAOIFI yaitu standar pengungkapan pelaporan keuangan, Islamic Reporting Index dan dari malaysia adalah Islamicity Disclosure Index yang mencakup Shariah Cmplinace, Governance dan Environmental/Social reporting.

Karena ada kesamaan beberapa point pada setiap indeks, peneliti menggabungkan beberapa indeks agar saling melengkapi. Contoh: dalam IDI dan AAOIFI hanya menyarankan indeks bahwa bank syariah harus mengeluarkan laporan sumber dan penggunaan zakat, tapi ISR memberikan perincian indeks mengenai zakat lebih detail, seperti 
metode perhitungan zakat apa yang digunakan, mengapa ada dana zakat yang tidak disalurkan. Contoh di atas diharapkan memberikan gambaran secara detail dalam satu poin seperti contoh di atas yaitu zakat. Langkah berikutnya peneliti menghilangkan indeks yang dianggap tidak dapat diterapkan secara umum dan yang tidak sesuai dengan prinsip dan hukum Islam.

Jika dilihat berdasarkan tujuan, indeks yang dikeluarkan AAOIFI memiliki tujuan pengungkapan lebih banyak kepada owner dan investor. Indeks lain adalah Islamicity disclosure indeks (IDI) merupakan suatu alternative indeks yang dikeluarkan oleh Hameed (2003) yang mencakup berbagai aspek. Termasuk yang menggambarkan karakteristik bank syariah, terlihat dalam komponen shariah compliance. Komponen governance merupakan suatu hal penting dalam menjalankan usaha, dan komponen social/environmental menyajikan suatu pertanggungjawaban kepada pihak luar dan internal (karyawan) selama menjalankan operasional bank syariah.

Dilain hal, ISR yang merupakan ciri khas dari Corporate Social Responsibility cukup memadai untuk informasi yang disajikan kepada sosial (sesama) dan lingkungan. Secara emplisit ISR menyajikan lebih detail mengenai social dibanding pada dua disclosure lainnya. Karena ISR fokus pada dan sosial (sesama), maka aspek-aspek dalam pelaporan keuangan kurang diperhatikan. Sedangkan standar dari AAOIFI memberikan gambaran akuntansi yang sangat kental, karena tertulis jelas pengungkapan tersebut untuk pelaporan keuangan. Padahal dalam Triyuwono (2012) menyirat makna bahwa akuntansi adalah disiplin dan praktik yang dibentuk dan membentuk lingkungannya. Dari pernyataan ini member makna bahwa akuntansi syariah dibentuk dari entitas syariah seharusnya membentuk output yang bernafaskan Islami yaitu secara seimbang tidak hanya pada pelaporan keuagnan saja tapi juga pada kepedulian sosial. Dari uraian sementara di atas mengenai pengembangan indeks pada penelitian ini dapat dilihat dengan skema mengikuti Hardiyanti (2012), gambar di bawah ini:

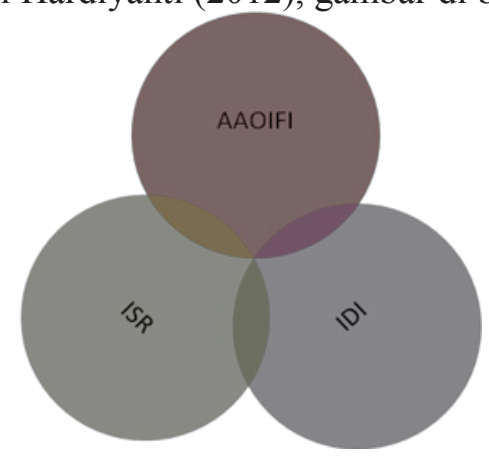

Gambar 1. Pengembangan Indeks Pengungkapan

Setelah melakukan kompilasi beberapa akun. Kemudian ada beberapa point indeks akun yang dihapus dalam tiga sumber indeks (standar pelaporan keuangan AAOIFI, Islamicity Disclosure Index (IDI) dan Islamic Social Reporting (ISR) Index) seperti energy saving, manajemen lingkungan. Mengingat bank adalah lembaga keuangan yang menghimpun dan menyalurkan pembiayaan serta memberikan jasa perbankan lainnya bukan fokus pada lingkungan hidup dan fakta yang meunjukan bahwa pada sturktur organisasi bank syariah tidak ada manajemen yang mengatur mengenai lingkungan, maka point tersebut tidak diperlukan sehingga keluar dari indeks.

Indeks lain yang dikeluarkan adalah governance (IDI) karena (1) berupa angka seolah memberikan kesan sebuah kewajiban, padahal tidak setiap negara memiliki peraturan dengan angka terkait tersebut (2) untuk penelitian berikutnya, jika variabel independen menggunakan CG maka tidak akan terjadi hubungan kausalitas dan (3) dalam peraturan bapepam, tidak pernah termuat pengungkapan untuk governance (PBI mensyaratkan pengungkapan laporan CG, (4) beberapa bank membuat laporan CG tersendiri di luar Annual Report 
Indeks lain yaitu rasio gaji antar gender pada Indeks Islamic Social Reporting dihapus, karena tidak sesuai dengan QS. An-Nahl ayat 97 yang tidak membedaakan upah pekerja antar gender. Ayat tersebut memberi makna bahwa baik laki-laki maupun perempuan mendapatkan upah yang layak dan tidak membedakan gender.

Value Added Statement adalah point yang ada di indeks IDI, dan yang mengejutkannya pada penelitian Hameed et al (2013) juga tidak satu pun Bank Syariah baik Bank Bahrain maupun Bank Syariah di Malaysia mengeluarkan Value Added Statement. Dalam tataran teoritis pun, Triyuwono (2012) dan Mulawarman (2008) menyatakan Value Added Statement merupakan gagasan atas laporan keuangan syariah sebagai pengganti Laporan laba rugi.

\subsection{Metode Content Analysis}

Menutur Krippendorf (2003), Contenty Analysis merupakan sebuah teknik riset untuk membuat replikasi dan kesimpulan yang valid dari teks-teks yang ada untuk isi yang mereka gunakan. Dan Menurut Muhadjir (2000) Content analysis merupakan analisis ilmiah tentang isi pesan suatu komunikasi, salah satunya dengan menggunakan criteria sebagai dasar klasifikasi. Carney (1972), ditemukan ada Tipe Content Analysis dengan mengkategorikan berdasarkan tema seperti yang dilakukan oleh Rizkiningsih (2012) yaitu menganalisis berdasarkan Tema dan berdasarkan score maksimal atas pengungkapan yang dilakukan setiap tahunnya. Pengungkapan dalam penelitian ini terbagi atas tujuh tema dari setiap Negara dengan memberikan nilai maksimal dan minimal setiap tema. Masing-masing tema memiliki beberapa point pengungkapan, seperti Tema Dasar Informasi Bank terdiri dari identitas, visi dan misi, sehingga Score maksimal (SM) ada 3 jika bank melakukan pengungkapan terhadap tiga point tersebut. Maka maksimal (MAX) menmberikan batas atas gambaran bahwa ada bank syariah melakukan pengungkapan penuh pada tema yang bersangkutan, dan mininal (MIN) bisa bernilai nol jika ada bank syariah yang tidak melakukan pengungkapan pada tema tersebut. Peneliti menambahkan persentase (\%) yang menggambarkan jumlah keseluruhan bank syariah di setiap negara dari setiap tema.

\subsection{Data dan Sampel}

Sampel pada penelitian ini menggunakan metode purposive sampling, yaitu yang memiliki kriteria sampel tertentu sesuai dengan yang dikehendaki peneliti. Adapun kriteria sampel adalah sebagai berikut:

1. Diakses melalui website www.aibim.com

2. Berbentuk Bank Umum Syariah dan memiliki website

3. Disajikan dalam Bahasa Inggris dan atau Bahasa Indonesia

4. Menyediakan annual report pada web bank syariah tersebut

Laporan Tahunan Bank Umum Syariah yang mudah diakses melalui internet pada situs bank terkait. Karena untuk para pengguna informasi, para analis dan pengguna lainnya bisa melihat dengan kemudahan memperoleh informasi perusahaan syariah. Data yang digunakan oleh peneliti adalah data sekunder berasal dari laporan tahunan dan laporan keuangan bank syariah.

Peneliti tidak menggunakan sampel Unit Usaha Syariah (UUS). UUS adalah bagian/divisi/unit syariah yang ada di bank konvensional. Karena Laporan tahunan masih merangkap dengan bank konvensional sehingga sulit membedakan pengungkapan mana yang menjadi pengungkapan UUS itu sendiri dengan pengungkapan induknya (bank konvensional). Perolehan data diambil dari www.aibim.com yang memuat daftar bank syariah di beberapa negara dan memberikan akses menuju website bank syariah di setiap Negara. 
3. HASIL DAN PEMBAHASAN

3.1. Indeks Pengungkapan Yang Baru

Tabel 1. Pengembangan Indeks Berdasarkan Sumber

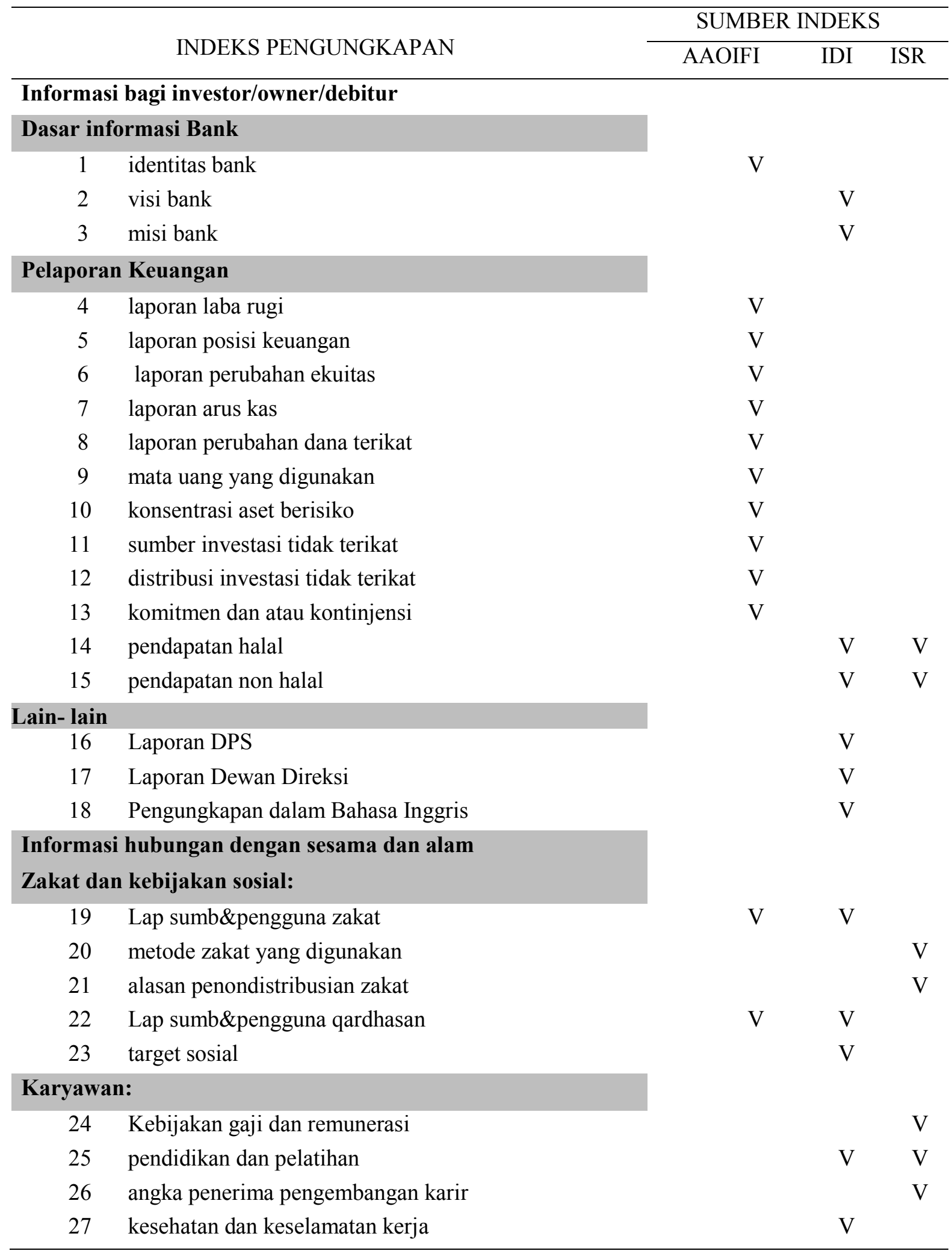




\begin{tabular}{clccc}
\hline & \multirow{2}{*}{ INDEKS PENGUNGKAPAN } & \multicolumn{3}{c}{ SUMBER INDEKS } \\
\cline { 2 - 4 } & & AAOIFI & IDI & ISR \\
\hline Pelanggan: & & \\
28 & kepuasan customer & $\mathrm{V}$ & \\
29 & keluhan dan tindakan yang diambil & $\mathrm{V}$ & \\
Informasi hubungan dengan Alam & & \\
30 & target lingkungan & $\mathrm{V}$ & $\mathrm{V}$ \\
31 & Perlindungan lingkungan & $\mathrm{V}$ & $\mathrm{V}$ \\
\hline
\end{tabular}

\section{Keterangan:}

AAOIFI : Standar untuk pelaporan keuangan diterbitkan AAOIFI Islamic Social Reporting (ISR) IDI : Islamicity Disclosure Index

Tabel 2. Keyword Pengungkapan

Penjelasan pencarian pengungkapan (terkait tabel 1.)

\begin{tabular}{|c|c|c|}
\hline No & Indeks Pengungkapan & Keyword \\
\hline & \multicolumn{2}{|l|}{ Dasar Informasi Bank } \\
\hline 1 & Identitas bank & Nama bank, alamat \\
\hline 2 & Visi & $\begin{array}{l}\text { Tujuan jelas, pandangan ke depan perusahaan } \\
\text { (biasanya ada tulisan vision) }\end{array}$ \\
\hline \multirow[t]{2}{*}{3} & Misi & $\begin{array}{l}\text { Tindakan dalam mencapai visi (biasanya ada } \\
\text { tulisa mission) }\end{array}$ \\
\hline & Pelaporan Keuangan & \\
\hline 4 & Laporan Laba Rugi & $\begin{array}{l}\text { Laporan keuangan berisi pendapatan dan beban- } \\
\text { beban menggambarkan kinerja }\end{array}$ \\
\hline 5 & Laporan Posisi keuangan & $\begin{array}{l}\text { Laporan keuangan berisi posisi keuangan terdiri } \\
\text { dari aset, liabilitas, dana syrikah temporer dan } \\
\text { ekuitas }\end{array}$ \\
\hline 6 & Laporan Perubahan ekuitas & $\begin{array}{l}\text { Judul laporan perubahan ekuitas, perubahan modal awal } \\
\text { sampai akhir atau perubahan laba ditahan }\end{array}$ \\
\hline 7 & Laporan Arus Kas & Berisi aktivitas opeerasi, investasi dan pendanaan \\
\hline 8 & $\begin{array}{l}\text { Laporan Perubahan Dana } \\
\text { Terikat }\end{array}$ & $\begin{array}{l}\text { Merupakan laporan dengan Judul "Dana Terikat" } \\
\text { yaitu dari simpanan Mudharabah Muqayyadah }\end{array}$ \\
\hline 9 & Mata Uang yang digunakan & $\begin{array}{l}\text { Mencantumkan mata uang, baik pada catatan atas } \\
\text { laporan keuangan atau pada laporan keuangan }\end{array}$ \\
\hline 10 & Konsentrasi Aset berisiko & $\begin{array}{l}\text { Pembiayaan yang diberikan bank dengan tingkat } \\
\text { risiko baik waktu ataupun sektor (credit risk) }\end{array}$ \\
\hline 11 & $\begin{array}{l}\text { Sumber investasi dana tidak } \\
\text { terikat }\end{array}$ & $\begin{array}{l}\text { Merupakan dari dana syirkah temporer, simpanan } \\
\text { pihak ketiga degan akad Mudharabah mutlaqah }\end{array}$ \\
\hline 12 & $\begin{array}{l}\text { Distribusi investasi dana tidak } \\
\text { terikat }\end{array}$ & $\begin{array}{l}\text { Merupakan alokasi dari sumber investasi dana } \\
\text { tidak terikat }\end{array}$ \\
\hline 13 & Komitmen dan kontinjensi & $\begin{array}{l}\text { Ada di bagian neraca-liabilitas, ada di Catatan atas } \\
\text { laporan keuangan perincian komitmen atau kontinjensi }\end{array}$ \\
\hline 14 & Pendapatan halal & $\begin{array}{l}\text { Secara jelas mencantumkan kata Islamic atau halal } \\
\text { dalam pendapatan }\end{array}$ \\
\hline 15 & Pendapatan non-halal & $\begin{array}{l}\text { Terdapat pada Laporan Sumber dan penggunaan } \\
\text { dana kebajikan }\end{array}$ \\
\hline
\end{tabular}

EQUITY VOL. 19 NO.2 


\begin{tabular}{|c|c|c|}
\hline No & Indeks Pengungkapan & Keyword \\
\hline & Lain-lain & \\
\hline 16 & Laporan DPS & $\begin{array}{l}\text { Memuat opini audit mengenai kesyariahan bank syariah } \\
\text { secara terperinci dari operasional, produk- produk, } \\
\text { pelaporan keuangan dan perhiungan zakat. bukan } \\
\text { secara garis besar saja. }\end{array}$ \\
\hline 17 & Laporan Dewan Direksi & $\begin{array}{l}\text { Memuat isi dari Direktur Utama/CEO, mengenai } \\
\text { kinerja tahun lalu dan prospektus tahun depan }\end{array}$ \\
\hline 18 & $\begin{array}{l}\text { Pengungkapan dalam Bahasa } \\
\text { Inggris }\end{array}$ & $\begin{array}{l}\text { Menyajikan seluruh laporan tahunan baik dengan } \\
\text { satu atau dua bahasa, baik dengan bahasa inggris saja } \\
\text { ada dengan bahasa inggris dengan bahasa lainnya. }\end{array}$ \\
\hline
\end{tabular}

\section{Zakat dan kebijakan sosial}

19 Laporan Sumber dan Penggunaan Dana Zakat

Laporan berisi besarnya sumber zakat baik dari bank atau non bank serta penyaluran zakat itu sendiri kepada yang berhak menerima (mustahiq)

20 Metode zakat yang digunakan

21 Alasan Penondistribusian zakat

Perhitungan besaran dana zakat yang yang dikeluarkan bank syariah

Saldo zakat yang tersisa dengan keterangan pada catatan atas laporan keuangan

Berisi pendapatan non-halal, denda dan

22 Laporan Sumber dan Penggunaan Dana kebajikan sebagainya yang di atur AAOIFI, serta penyalurannya.

23 Target sosial

Jelas menyebutkan sektor apa yang menjadi penyaluran dana sosial, lokasi dan tempatnya

\begin{tabular}{|c|c|c|}
\hline & \multicolumn{2}{|l|}{ Karyawan } \\
\hline 24 & Kebijakan gaji dan remuneasi & $\begin{array}{l}\text { Kebijakan perusahaan dalam memakmurkan } \\
\text { karyawan seperti persentase kenaikan gaji. }\end{array}$ \\
\hline 25 & Pendidikan dan Pelatihan & $\begin{array}{l}\text { Bentuk pendidikan dan pelatihan atau tujuan } \\
\text { kegiatannya dalam meningkatkan kompentensi } \\
\text { karyawan }\end{array}$ \\
\hline 26 & $\begin{array}{l}\text { Angka penerima pendidikan } \\
\text { pelatihan }\end{array}$ & Jumlah yang menerima pelatihan/pendidikan \\
\hline \multirow[t]{2}{*}{27} & Kesehatan dan keselamatan kerja & Program K3 atau ada tunjanga kesehatan \\
\hline & Nasabah & \\
\hline 28 & Kepuasan customer & $\begin{array}{l}\text { Pernyataan kepuasan dari pihak lain bukan dari peneliti } \\
\text { atau bank itu sendiri. Contoh, penghargaan yagn } \\
\text { menyatakan ada kepuasan nasabah atau testimony dari } \\
\text { nasabah itu sendiri }\end{array}$ \\
\hline
\end{tabular}

29 Keluhan nasabah

Penangangan keluhan nasabah atau tanggapan atas keluhan tersebut

\section{Lingkungan / alam}

30 Target Lingkungan

Lokasi dan tempat yang jelas

31 Perlindungan lingkungan/

Kontribusi langsung atau tidak langsung untuk pelestarian alam 


\subsection{Eliminasi Sampel}

Berdasarkan informasi perolehan data, tidak semua laporan tahunan setiap bank syariah dapat diperoleh. Dengan perincian sebagai berikut:

Tabel 3. Eliminasi Sampel

\begin{tabular}{cc}
\hline \multicolumn{1}{c}{ Keterangan pengeliminasian sampel } & Jumlah sampel \\
\hline Jumlah Negara dalam website www.aibim.com & $\mathbf{5 1}$ \\
Bank syariah yang bisa diestimasi bisa diakses & 60 \\
Web bank syariah masih dalam perbaikan & $(10)$ \\
Bahasa asing (arab, thailand, turkey, dan lainnya) & $\underline{(19)}$ \\
Total bank syariah yang bisa diakses annual report & 31 \\
\hline
\end{tabular}

Dari tabel 3. di atas menunjukan ada 31 bank syariah yang bisa diakses. Beberapa bank syariah tidak dapat di akses annual reportnya karena ada yang tidak memiliki web, peneliti terkendala dengan bahasa asing seperti Arab, Thailand, Turkey dan lainnya). Serta beberapa memiliki website yang masih dalam perbaikan.

\subsection{Hasil Content Analysis}

Dalam pengembangan indeks pengungkapan pada peneltian ini telah dihitung total setiap bank syariah kemudian melakukan content analysis berdasarkan Tema pada indeks pengungkapan sebagai berikut:

Tabel 4.:

Hasil Content Analysis Berdasarkan Tema Setiap Negara

\begin{tabular}{|c|c|c|c|c|c|c|c|c|c|c|c|c|c|c|c|c|c|}
\hline \multirow{3}{*}{ Tema } & \multirow{3}{*}{$\mathrm{SM}$} & \multicolumn{16}{|c|}{ Negara } \\
\hline & & \multicolumn{3}{|c|}{ Indonesia } & \multicolumn{3}{|c|}{ Malaysia } & \multicolumn{3}{|c|}{ Bahrain } & \multicolumn{3}{|c|}{ Qatar } & \multicolumn{3}{|c|}{ Iran } & UK \\
\hline & & $\operatorname{Max}$ & Min & $\%$ & Max & Min & $\%$ & $\operatorname{Max}$ & Min & $\%$ & $\operatorname{Max}$ & Min & $\%$ & Max & Min & $\%$ & Max \\
\hline $\begin{array}{c}\text { Dasar informasi } \\
\text { bank }\end{array}$ & 3 & 3 & 3 & 100 & 3 & 1 & 57 & 3 & 1 & 51 & 3 & 1 & 52 & 3 & 1 & 63 & 1 \\
\hline $\begin{array}{l}\text { Pelaporan } \\
\text { Keuangan }\end{array}$ & 12 & 11 & 3 & 68 & 9 & 5 & 62 & 12 & 4 & 55 & 8 & 5 & 45 & 7 & 5 & 50 & 7 \\
\hline Lain-lain & 3 & 3 & 1 & 70 & 2 & 0 & 90 & 3 & 2 & 81 & 3 & 2 & 62 & 2 & 2 & 67 & 3 \\
\hline $\begin{array}{c}\text { Zakat dan } \\
\text { Kebijakan Sosial }\end{array}$ & 5 & 4 & 0 & 41 & 2 & 0 & 15 & 5 & 0 & 23 & 1 & 0 & 6 & 0 & 0 & 0 & 1 \\
\hline Karyawan & 4 & 4 & 0 & 42 & 1 & 0 & 10 & 2 & 0 & 16 & 2 & 0 & 18 & 3 & 0 & 28 & 1 \\
\hline Nasabah & 2 & 2 & 0 & 21 & 0 & 0 & 0 & 2 & 0 & 11 & 0 & 0 & 0 & 0 & 0 & 0 & 0 \\
\hline Alam/lingkungan & 2 & 2 & 0 & 24 & 1 & 0 & 6 & 0 & 0 & 0 & 1 & 0 & 0 & 0 & 0 & 0 & 0 \\
\hline
\end{tabular}

Sumber:data diolah;

Ket: $\mathrm{SM}=$ Score Maksimal

Lampiran 6 sampai lampiran 9

Tabel 4. menggambarkan content analysis berdasarkan tema untuk 6 negara yaitu Indonesia, Malaysia, bahrain, Qatar, Iran dan Inggris, berikut ini adalah tabel content analysis berdasarkan tema di setiap negara:Berdasarkan Tabel 4. Tema Dasar Informasi Bank, seluruh annual report bank syariah di Indonesia mencantumkan visi, misi dan identitasnya. Sedangkan Mayoritas bank syariah di Malaysia tidak mencantumkan (memiliki misi), fakta tersebut terjadi pada Bank Muamalat Malaysia dan Kuwait Finance House tahun 2008. Persentase dari keseluruhan bank syariah di Malaysia tidak berdeda jauh dengan bank syariah di Bahrain. Hanya sebagian bank syariah di Qatar dan Iran yang mencantumkan visi misinya. Padahal dalam Hameed et al (2003) visi misi bank menggambarkan pencapaian tujuan 
(falaah). Dari 6 negara mengindikasikan Indonesia memiliki komitmen yang cukup kuat dan terarah dalam menjalankan operasional perbankan syariah.

Pada tema Lain-lain yang berhubungan dengan investor, terdapat point pengungakapan berupa laporan DPS. Karena standar AAOIFI, DPS wajib mengeluarkan pernyataan apakah lembaga sudah sesuai syariah dalam hal opersional, revieu pelaporan keuangan, perhitungan zakat dan sebagainya. Namun yang ditemukan adalah ada beberapa bank syariah masih melaporkan secara garis besar saja bahwa entitas tersebut sudah sesuai syariah. Hal ini tidak dimasukan peneliti kedalam hitungan. Hanya yang secara jelas apa-apa saja yang sesuai syariah yang akan dihitung sebagai pengungkapan pernyataan DPS.

Tema Pelaporan Keuangan, content tertinggi berada di bank syariah Al-Baraka periode 2009-2011 dan bank syariah Khaleji periode 2009 di Bahrain,dari laporan laba rugi hingga pendapatan non halal, seluruhnya diungkapkan oleh bank tersebut. Mengingat juga indeks- indeks pada pelaporan keuangan banyak merujuk dari standar AAOIFI (di Bahrain). Sedangkan di Indonesia, bank yang paling banyak memberikan kontribusi pengungkapan atas pelaporan keuangan ada pada Bank Syariah Mandiri periode2007-2009 dengan 11 indeks pengungkapan.

Dua jenis laporan keuangan yang membedakan entitas syariah dengan non syariah adalah harus memiliki (1) Laporan Sumber dan Penggunaan Dana Zakat dan (2) Laporan Sumber dan Penggunaan Dana Kebajikan (Qardhul Hasan). Dua laporan ini tidak dimasukan ke dalam tema pelaporan keuangan karena kedua laporan tersebut bersifat sosial. Pada bank syariah di Indonesia, dua laporan ini disajikan oleh sedikit bank, yaitu hanya pada Bank Syariah Mandiri (BSM) dan Bank Muamalat Indonesia (BMI). Dari tabel 4 terlihat hanya 1 angka pada pelaporan sosial yaitu hanya Inggris yang mengungkapkan metode zakat yang digunakan,. Namun jika dilihat dari content secara terperinci, BMI baru menyajikan dua laporan ini pada tahun 2012, mungkin dikarenakan pemberlakuakn PSAK Syariah baru diresmikan pada tahun tersebut. PSAK Syariah diberlakukan untuk entitas yang go public yang hingga saat ini pun hanya BMI yang menjadi bank syariah go public di Indonesia.

Pada Negara lain, hanya beberapa bank syariah juga yang menyajiikan dua laporan tersebut. Walaupun bank syariah tersebut tidak menyajikannya, hampir setiap bank syariah di Bahrain melakukan pembayaran zakat atas entitas. Terlihat dari metode zakat yang digunakan, mereka mengacu pada standar zakat AAOIFI, sedangkan di Indonesia, bank syariah yang mengungkapkan metode zakat hanya BSM dengan metode 2,5\% dari laba. Sehingga disimpulkan baru BSM yang melakukan pembayaran zakat atas entitas syariah. Dua laporan tersebut baru disajikan oleh BMI pada tahun 2012 karena zakat atas entitas syariah sudah di atur dalam PSAK Syariah No. 109.

Namun bukan berarti bank syariah di Indonesia tidak membayar zakat. Tidak diungkapkannya secara jelas apakah bank syariah sebelum tahun 2012 melakukan pembayaran zakat atas entitasnya atau tidak karena tidak mencantumkan metode zakat apa yang digunakan saat membayar. Fenomena yang ditemukan oleh bank syariah lain, mereka menyalurkan zakat kepada yang berhak (mustahiq) melalui lembaga zakat nasional seperti BAZNAS, ZIS. Lain halnya BMI, sebelum ada ketetapan kewajiban untuk pelaporan zakat, BMI sudah membentuk anak perusahaan yang dikhususkan sebagai penghimpun dan penyalur dana zakat, infaq, sodaqoh.

Untuk bank syariah di Malaysia dan Bahrain, semua entitas syariah mendapatkan opini dari Shariah Supervisory Board (di Indonesia di kenal dengan Dewan Pengawas Syariah) menyatakan bahwa perhitungan zakat untuk entitas sudah sesuai dengan prinsip syariah. Memang yang kita kenal zakat diperuntukan oleh perorangan bukan untuk suatu badan, namun berdasarkan sumber hukum Islam ketiga yaitu Ijma (kesepakatan para cendikiawan muslim) menjadi sumber rujukan atas pembayaran zakat bagi entitas. Ijma ini tertuang dalam Standar Syariah yang diterbitkan AAOIFI. Standar tersebut menjadi rujukan banyak negara seperti Indonesia dalam merumuskan SAK Syariah kemudian disesuaikan dengan peraturan yang ada di Indonesia. 
Metode-metode untuk zakat entitas cukup banyak yang digunakan oleh mayoritas bank syariah di Bahrain dan Malaysia adalah net asset method seperti oleh bank syariah Al-Khair (Unicorn), demikian juga dilakukan oleh Europian Investment Islamic Bank di Inggris dan Khaleji di Bahrain, mereka menyatakan mengikuti dari Financial Accounting Standard No. 9 dalam standar akuntansi keuangan AAOIFI. Ada juga yang menggunakan net invested fund method oleh bank First Energy Bank di Bahrain,. Uniknya pada salah satu bank syariah di Malaysia yaitu Affin Islamic Bank Berhard memiliki Manajemer Zakat dan Promosi. Hal ini berkaitan dengan pernyataan Triyuwono (2012) sebagai penggagas Shariah Enterprise Theory menyatakan bahwa seharusnya entitas syariah tidak lagi profit oriented tapi berubah menjadi stockholder dan zakat oriented. Keunikan lainnya adalah bank syariah di Malaysia menunjukan bahwa Corporate Social Responsibility (CSR) yang mereka keluarkan seluruhnya berasal dari zakat. Pada bagian CSR dalam annual reportnya, bank syariah mengungkapkan zakat-zakat tersebut disalurkan kepada mereka yang berhak. Sedangkan bank syariah di Indonesia dan Bahrain, zakat disalurkan kepada yang berhak, dana untuk CSR tersendiri lagi.

Untuk target sosial, hanya dilakukan bagi yang jelas mengungkapkan secara detail sektor apa yang dituju, memang secara keseluruhan, hampir semuanya memiliki subbab tersendiri bahwa perusahaan melakukan CSR, tapi tidak secara detail sektor mana yang ditempatkan. Hal tersebut menjadi tidak masuk dalam kategori cheklist pengungkapan.

Tema Karyawan, dimasukan untuk memperhatikan kelayakan kehidupan dalam lingkungan kerja sebagai karyawan. Sehingga indeks ini tidak bersifat egoistic yang memperlihatkan hubungan manajer dengan pemilik, tapi juga memperhatikan stakeholder lainnya. Dalam hal ketepatan pembayaran gaji, tidak diragukan lagi bahwa setiap bank memiliki administrasi dengan tekhnologi informasi yang tinggi sehingga setiap bulan sudah autocredit masuk rekening setiap karyawan. Peneliti memasukan apakah ada kebijakan atas gaji dan pengembangan karir yang memungkinkan karyawan ada hirarki dan kompeten dalam bidangnya serta kesehatan dan atau keselamatan kerja.

Di Indonesia, secara jelas dalam laporan catatan atas laporan keuangan pada bagian ekspense, menyatakan secara jelas gaji karyawan naik beberapa persen seperti pada Bank Muamalat Indonesia. Dengan demikian kebijakan gaji dan remunerasi dimasukan kedalam indeks. Sedangkan kebijakan gaji di Negara lainnya tidak menyatakan secara jelas kenaikan setiap tahun, namun mereka memberikan profit sharing atas kinerja yang dilakukan. Untuk kesehatan, peneliti memasukan tunjangan kesehatan atau fasilitas kesehatan yang diberikan perusahaan kepada karyawan ke dalam cheklist pengungkapan.

Pendidikan dan pelatihan banyak dilakukan dalam memajukan sumber daya insani setiap karyawan bank syariah. Beberapa bank di Bahrain secara intens memberikan training mengenai money laundry. Pada bank syariah di Indonesia, karyawan diberikan pelatihan lebih intens pada bidangnya agar semakin mahir dan profesional dalam pencapaian target perusahaan. Di Malaysia, seperti bank syariah Kwait Finance House memberikan training lebihditekankan kepada bank syariah secara umum dan behavioral daily work. Sedangkan pada Bank masraf Al-Ryan di Qatar, pendidikan kepada karyawan dilakukan dengan $e$ learning untuk mengurangi biaya.

Untuk pengungkapan dengan Tema Nasabah/pelanggan, peneliti hanya menemukan pengungkapan tersebut pada Negara Bahrain dan Indonesia. Peneliti memasukan kepuasan 
nasabah jika dalam laporan tahunan dinyatakan oleh pihak lain (bukan oleh bank itu sendiri ataupun oleh peneliti). Pada bank syariah yang memiliki kepuasan nasabah, diraih oleh Bank Syariah Mandiri dan Bank Mumalat Indonesia, secara tidak langsung dengan penghargaan yang diraih sebagai penghargaan atas kepuasan nasabah. Di Bahrain, hanya bank Maskan yang memuas testimoni atas kepuasan nasabah tertera lengkap dengan nama dan usaha serta besarnya pinjaman kepada nasabah tersebut. Selain itu pada bank tersebut, dalam testimoni memuat bahwa pemberian pinjaman sangat memperhatikan unsur syariah seperti untuk usaha female saloon.

Keluhan-keluhan yang dimasukan ke dalam pengungkapan adalah keluhan yang secara jelas ditanggapi. Seperti bank syariah Khaleji di Bahrain mengungkapkan secara jelas keluhan nasabah di terima via internet dan telpon. Di Indonesia, Bank Syariah Mandiri tahun 2011 mengungkapkan angka (banyaknya) keluhan konsumen dan berapa saja yang sudah ditanggapi. Sayangnya, di Malaysia tidak satupun sehingga angka content analisisnya terlihat nol.

Pengungkapan dengan Tema Lingkungan/Alam dalam Tabel 4. menggambarkan bahwa bank syariah di Bahrain tidak satu pun melakukan pengungkapan yang berhubungan dengan alam. Sedangkan di Malaysia angka maksimal hanyasebesar 1 yaitu diperoleh pada bank syariah Kwait Finance House dan Hong Leong Islamic Bank untuk indeks Perlindungan lingkungan. Tidak satu bank pun mengungkapnkan adanya target lingkungan. Seperti yang dilakukan oleh Kwait Finance House, hanya mengungkapkan melakukan cocok tanam dengan pihak-pihak sekolah.

Hamid dan Nordin (2001) menyatakan bahwa pengenalan lembaga keuangan syariah diperkenalkan sejak sekolah. Mungkin ini alasan yang menjadikan Kwait Finance House bekerja sama dengan sekolah-sekolah dalam pencocokan tanam. Hong Leong Islamic Bank juga memberikan promosi melalui kartun Upin Ipin. Tidak heran jika lembaga-lembaga syariah di Malaysia berkembang maju. Hal ini dikarenakan pengenalan mengenai syariah sejak usia dini di Negara tersebut.

Di Qatar pada Bank Barwa tahun 2011 dengan less paper dan electronic statement. Di Indonesia pengungkapan dengan tema lingkungan alam hanya diungkapkan oleh Bank Syariah Mandiri dan Bank Mumalat Indoensia yang secara langsung melakukan penghijauan disertai dengan lokasi sehingga angka maksimal dalam content pengungkapan mencapai batas atas yaitu point perlindungan lingkungan dan target lingkungan. Bank-bank syariah lebih banyak tidak mengungkapkan tema lingkungan alam, hal ini diyakini karena bank sebagai lembaga keuangan yang tidak berhubungan dengan alam. Namun jika dilihat dari Shariah Enterprise theory, sebuah entitas syariah memiliki amanah sebagai khalifat filArdh dalam mendistribusikan kekayaan tidak hanya kepada golongan tertentu tapi juga kepada sosial, karywan termasuk kepada alam . Karena secara sadar atau tidak sadar perusahaan sudah melakukan eksploitasi kepada karyawan dan alam (Triyuwono, 2012).

Tema-tema yang bersifat sosial di atas memberikan gambaran bahwa masih sedikit bank syariah yang melakukannya terutama pengungkapan yang berhubungan dengan alam. Hal tersebut terlihat dari persentase tema-tema pengungkapan zakat social, karyawan, pelanggan dan alam yang masih berada di bawah 50\% dari keseluruhan bank syariah baikdi Indonesia, Malaysia dan Bahrain.

Bank syariah di berbagai negara lebih banyak konsen pada pelaporan keuangan dan pengungkapan lain yang sifatnya ditujukan pada calon investor dan pemilik saham untuk memperbesar dan menjaga keberlangsungan kehidupan perusahaan. Padahal disadari atau tidak, keberlangsungan usaha (going concern) entitas syariah tersebut bukan hanya dari sistem.Seperti bank Muamalat yang tahan krisis pada tahun 1998 dikatakan bertahan karena produksyariahnya, tapi juga tanggung jawab sosial dan zakat yang dijalankan entitas tersebut. Hal tersebut tersirat dalam QS Al-Baqarah:261. Tidak hanya itu, Bank Bukopin Syariah 
menyatakan hal yang sama dalam laporan tahunan 2012 pada subbab CSR bahwa"Perseroan meyakini bahwa kontribusi yang diberikan secara intens dan berkesinambungan dalam kegiatan tanggung jawab sosial perusahaan akan membawa manfaat dan nilai lebih dalam jangka panjang". Sehingga pandangan bank syariah dari masyarkat bisa tercipta tidak hanya syariah dalam produk tapi juga dalam corporate culture dan manajemennya dalam memperhatikan stakeholder (tidak hanya stockholder).

\section{SIMPULAN}

Indeks yang diformulasikan kembali telah merefleksikan hubungan dengan selluruh stakeholder. Untuk kedepannya pengembangan indeks pengungkapan dapat menambahkan telaah literature pada indeks pengungkapan yaitu regulasi dari Negara lain agar indeks pengungkapan bisa digunakan diseluruh dunia yang bisa membedakan pengungkapan mana yang wajib dengan sukarela. Telaah lainnya yaitu dengan pendekatan nilai-nilai agama agar lebih mantap dalam mencerminkan indeks pengungkapan baik secara umum dan secara syariah.

Content analysis menunjukan bahwa bank-bank syariah masih lebih banyak konsen pada pengungkapan pelaporan keuangan dibandingkan dengan pengungkapan yang bersifat sosial kepada seluruh stakeholder. Menarik setiap bank memiliki keunikan atas kebijakan. masing-masing disesuaikan dengan kondisi suatu lingkungan di negaranya dan tujuan dari entitas tersebut. Bagaimana pun juga bank syariah juga tetap menonjolkan karakter keuangan seperti laporan zakat infaq sedekah yang terukur dengan uang, padahal ruang lingkung sedekah tidak hanya mencakup uang.

\section{DAFTAR PUSTAKA}

AAOIFI. (2003). Accounting, Auditing and Governance Standar of Islamic Financial Instituions. Accounting and Auditing Organization for Islamic Institution. Manama, Bahrain

AAOIFI. (2010). Accounting, Auditing and Governance Standar of Islamic Financial Instituions. Accounting and Auditing Organization for Islamic Institution. Manama, Bahrain

DSAK. (2012). Pernyataan Standar Akuntansi Keuangan No. 101 Tentang Penyajian Laporan Keuangan Syariah. Ikatan Akuntan Indonesia. Jakarta

Fitria, S., \& Hartati, D. (2010). Islam\& Tanggung Jawab Sosial: Studi Perbandingan Pengungkapan Berdasarkan Global Reporting Initiative Indeks \& Islamic Social Reporting. Purwokerto. Simposium Nasional Akuntansi XIII.

Hameed, A. Wirman, A., Alrazi, B., Nazli, M,. (2003). Alternative Disclosure \& Performance Measures for Islamic Banks. Paper Presented in the International Conference on Information System and Islam at the IIUM. Kuala Lumpur. Hal. 1-34

Haniffa, R. (2002). Social Reporting Disclosure: An Islamic Perspective. Indonesian Management and Accounting Research. Vol .1 No.2 128-146

Hanniffa, R. Hudaib, M. (2007). Exploring the Ethical Identity of Islamic Banks via Communication in Annual Report. Journal of Business Ethic. 76 pp 97-116 
Harahap, S.S., (1997). Akuntansi Islam. Bumi Aksara. Jakarta

Harahap, S.S., (2001). Kritik Terhadap Perbankan Syariah, IAI \& AAOIFI. Media Riset Akuntansi, Auditing dan Informasi. Vol. 1, No.3. Universitas Trisakti

Harahap, S.S., (2002). The Disclosure of Islamic Value - annual Report The Analysis of Bank Muamalat Indonesia's Annual Report. Journal of Islamic Economics. Iqtisad.

Hardiyanti, S.(2012). Analisis Hubungan Shari'a Governance Structure Terhadap Tingkat Pengungkapan CSR pada Perbankan Syariah di Indonesia. Skrispsi. Universitas Indonesia

Hamid, A.H.A.\& Nordin, N.A.M., (2001). A Study of Islamic Banking Education and Strategy For The New Millenium - Malaysian Experience. International Journal of Islamic Financial, Vol. 2 No. 4

Hasan, A \& Harahap, S.S. (2010). Exploring Corporate Social Responsibility Disclosure: The Case of Islamic Bank. International Journal of Islamicand Middle Eastern Finance and Mangement. Vol. 3 No. 3 pp 203-227

Krippendorff, K. (2003). Content Analysis: An Introduction to Its methodology $2^{\text {nd }}$ Edition. SAGE Publication. California.

Muhadjir. N. (2010). Metodologi Penelitaian Kualitatif Edisi IV. Rake Sarasin. Yogyakarta

Mulawarman, A.D. (2007c). Menggagas Laporan Keuangan Syariah Berbasis Trilogy Maisyah - Rizq - Maal. Unpad Bandung. Simposium Nasional Ekonomi Islam III

Mulawarman, A.D. (2007d) .Menggagas Neraca Syariah Berbasis Maal: Kontekstualisasi "Kekayaan Altruistik Islami". Jakarta FEUI. The $1{ }^{\text {st }}$ Accounting Confenrence

Mulawarman, A.D. (2008). Laporan Keuangan Syari'ah Berbasis Tazkiyah. Disertasi. Fakultas Ekonomi Universitas Brawijaya. Malang

Putri, D.R. (2013). Analisis Peran DPS Berdasarkan Surat Keputusan DSN-MUI dan PBI (Studi Kasus: PT. Bank XYZ). Skripsi. Universitas Indonesia

Rizkiningsih, P. (2012). Faktor-faktor yang Mempengaruhi Pengungkapan ISR: Studi Empiris pada Bank Syariah di Indonesi, Malaysia dan Negara-negara GCC. Skripsi. Universitas Indonesia.

Triyuwono, I. (2000). Akuntansi Syariah: Implementasi Nilai Keadilan dalam format Metafora Amanah. Jurnal Akuntansi dan Auditing Indonesia. Vol. 4 No. 1, hal 1-34

Triyuwono, I. (2006). Akuntansi Syariah: Menuju Puncak Kesadaran Tuhan Manunggaling Kawulo-Gusti. Pidato Pengukuhan Guru Besar Akuntansi Syariah. Universitas Brawijaya. Malang

Triyuwono, I. (2012). Perspektif, Metodologi dan Teori Akuntansi Syariah, edisi dua. Jakarta. Rajawali Pers. 